\title{
Faktor Dominan Perilaku Berisiko terhadap Melahirkan Usia Anak
}

\section{Dominant Risk Behavior Factors for Childbirth Young Age}

\author{
Aprina $^{1}$, Titi Astuti ${ }^{2}$ \\ Jurusan Keperawatan, Politeknik Kesehatan Tanjung Karang, Indonesia
}

\section{ARTICLE INFO}

\section{Article history}

Received date

13 Nov 2020

Revised date

23 Nov 2020

Accepted date

30 Nov 2020

\section{Keywords:}

Behaviour;

Childbirth;

Young age.

\section{Kata kunci:}

Perilaku;

Melahirkan;

Usia anak.

\begin{abstract}
ABSTRAK
The impact of early marriage, among others, is related to reproductive health. Lampung Province is $10.70 \%$ and is the 12th of 22 provinces where the prevalence of child marriage is still above the national average. The purpose of this study is to determine the risk behavior of giving birth to teenagers in Tanggamus Regency in 2020. This type of research is quantitative, analytical research design with a cross-sectional approach. Data analysis was univariate, bivariate, and multivariate. The results of the study were 132 $(53,7 \%)$ respondents with good knowledge, $143(58,1 \%)$ respondents with a positive attitude, $149(60,6 \%)$ respondents with higher education, $164(66,7 \%) \%)$ respondents with sufficient economic status, as many as $168(68.3 \%)$ respondents with premarital sex, as many as $78(31,7 \%)$ respondents with a positive physical environment, as many as 133 $(54,1 \%)$ respondents with positive beliefs, as many $140(56,9 \%)$ respondents with a positive role as an officer, as many as $137(55,7 \%)$ respondents with a negative parent role, as many as $176(71,5 \%)$ respondents with a positive socio-cultural role, as many as $164(66,7 \%)$ respondents who did not give birth to the age of the child. There is a relationship between knowledge, attitudes, economic status, premarital sex, physical environment, beliefs, and customs on the behavior of giving birth to teenagers. There is no relationship between the role of health workers, the role of parents on the behavior of giving birth to adolescents, the dominant factor in giving birth to children in Tanggamus Regency in 2020 is premarital sex.
\end{abstract}

Dampak dari pernikahan dini antara lain, terkait dengan kesehatan reproduksi. Provinsi Lampung Sebesar $10,70 \%$ dan merupakan urutan ke 12 dari 22 provinsi dengan prevalensi perkawinan anak masih ada di atas rata-rata nasional. Tujuan penelitian ini untuk mengetahui perilaku beresiko melahirkan anak usia remaja di Kabupaten Tanggamus Tahun 2020. Jenis penelitian kuantitatif, desain penelitian analitik dengan pendekatan cross sectional. Subjek penelitian Ibu Nifas dan objek penelitian ini adalah pengetahuan,sikap, Pendidikan, social ekonomi, seksual pra nikah, lingkungan fisik, kepercayaan, Peran petugas kesehatan, Peran orang tua, adat istiadat, remaja melahirkan usia anak. Pengumpulan data menggunakan kuesioner, analisis data secara univariat, bivariat dan multivariat. Hasil penelitian dari 246 responden sebanyak $132(53,7 \%)$ responden dengan pengetahuan baik, sebanyak $143(58,1 \%)$ responden dengan sikap positif, sebanyak $149(60,6 \%)$ responden dengan pendidikan tinggi, sebanyak 164 $(66,7 \%)$ responden dengan status ekonomi cukup, sebanyak $168(68,3 \%)$ responden dengan seksual pra nikah, sebanyak $78(31,7 \%)$ responden dengan lingkungan fisik positif, sebanyak $133(54,1 \%)$ responden dengan kepercayaan positif, sebanyak 140 $(56,9 \%)$ responden dengan peran petugas positif, sebanyak $137(55,7 \%)$ responden dengan peran orang tua negatif, sebanyak $176(71,5 \%)$ responden dengan sosial budaya positif, sebanyak $164(66,7 \%)$ responden dengan yang tidak melahirkan usia anak. Ada hubungan pengetahuan, sikap, status ekonomi , seksual pra nikah, lingkungan fisik, kepercayaan, adat istiadat terhadap prilaku melahirkan anak usia remaja. Tidak Ada hubungan hubungan Peran petugas kesehatan, Peran orang tua terhadap prilaku melahirkan anak usia remaja, faktor dominan terhadap melahirkan usia anak di Kabupaten Tanggamus Tahun 2020 adalah seksual pranikah.

\section{Corresponding Author:}

Aprina

Jurusan Keperawatan, Politeknik Kesehatan Tanjung Karang, Indonesia

Email: aprinamurhan@yahoo.co.id 


\section{PENDAHULUAN}

Masa remaja merupakan masa peralihan antara masa kehidupan anak-anak dan masa kehidupan orang dewasa yang ditandai dengan pertumbuhan dan perkembangan biologis dan psikologis. Secara biologis ditandai dengan tumbuh dan berkembangnya seks primer dan seks sekunder sedangkan secara psikologis ditandai dengan sikap dan perasaan, keinginan dan emosi yang labil atau tidak menentu (Hidayati \& Farid, 2016). Banyak remaja mengalami maturity-gap yaitu perbedaan kematangan secara fisik dan mental. Perbedaan kematangan ini dapat mendorong remaja untuk melakukan hal-hal yang beresiko (Aprianti, Shaluhiyah, \& Suryoputro, 2018).

Pada penelitian Nawati (2018) Dampak kehamilan yang tidak diinginkan terhadap perawatan kehamilan di Kota Bogor teridentifikasi, yaitu: (1) masalah psikososial dampak dari kehamilan tidak diinginkan, (2) penolakan terhadap kehamilan dan (3) kurangnya perawatan kehamilan. Sedangkan dampak kehamilan yang tidak diinginkan terhadap perawatan bayi teridentifikasi yaitu butuh waktu untuk menerima bayi.

Penelitian lain yang dilakukan oleh Singh, Rai, Alagarajan, dan Singh (2012) di India juga menunjukkan bahwa kurangnya pemanfaatan perawatan kehamilan oleh wanita yang mengalami kehamilan tidak diinginkan. Hasil penelitian Dye, et al. (1997) dalam Dini, dkk. (2016) menyatakan bahwa ibu yang mengalami kehamilan tidak diinginkan berpeluang 2,12 kali untuk tidak memberikan ASI secara eksklusif kepada bayinya. Sedangkan penelitian yang dilakukan pada 5 negara Demographic Health Suervey (DHS) analisis oleh Marston \& Cleland (2003) menemukan adanya risiko tinggi imunisasi tidak lengkap pada satu tahun pertama pada kelahiran yang tidak diinginkan.

Masalah psikososial dalam keluarga yang tidak siap menerima kehamilan dan bayi adalah faktor internal dari kehamilan tidak diinginkan. Hal ini sesuai dengan penelitian kualitatif dari Izugbara \& Egesa (2014) partisipan melaporkan merasa takut, marah, dan putus asa saat mengetahui bahwa mereka telah hamil secara tidak sengaja: "Ketika saya tahu, saya sangat ketakutan, saya hampir bunuh diri, saya tidak tahu harus memulai dari mana". Data yang dikumpulkan menunjukkan bahwa wanita menyalahkan diri mereka sendiri atas kehamilan yang tidak diinginkan. Hasil penelitian kualitatif Widyoningsih (2011) dengan hasil penelitian adanya stres yang dirasakan keluarga, meliputi stres fisik, stres finansial, stres psikologis dan stres sosial (Nourollahpour Shiadeh, 2016).

Dalam sepuluh (10) tahun terakhir, hanya ada penurunan kecil untuk perkawinan anak di Indonesia yaitu 3,5 poin persen. Pada Oktober 2019, Pemerintah Indonesia (Presiden RI, 2019) mengesahkan Undang-Undang nomor 16 tahun 2019 yang merupakan perubahan atas UU nomor 1 tahun 1974 tentang Perkawinan. Di tahun 2018, $11,21 \%$ perempuan 20-24 tahun menikah sebelum mereka berumur 18 tahun. Persentase Perempuan Usia 20-24 tahun yang Usia Perkawinan Pertamanya Kurang dari 18 Tahun menurut Provinsi tahun 2018, tertinggi di Kalimantan Tengah sebesar 19,13\% dan terendah di DKI Jakarta sebesar 4,06\% sedangkan di Provinsi Lampung Sebesar $10,70 \%$ dan merupakan urutan ke 12 dari 22 provinsi dengan prevalensi perkawinan anak masih ada di atas rata-rata nasional (Badan Pusat Statistik, 2020) .

Persentase perkawinan remaja perempuan menurut Kecamatan di Provinsi Lampung tahun 2016 tertinggi ada di Kecamatan Ulubelu sebesar $30 \%$, diikuti Bengkunat Belimbing 29\%, Pematang Sawah 27\%, Suoh 27\%, Gedung Surian 26\%, Belalau 26\%, Rawajitu Utara 26\%, Mesuji 25\%, Muara Sungkai 25\%, Bandar Mataram 25\% dan Panca Jaya $2 \%$. Proporsi kehamilan usia 10-54 tahun di Provinsi Lampung adalah 3,9\%. Di antara penduduk perempuan 1054 tahun tersebut, terdapat kehamilan pada umur remaja (15-19 tahun) adalah 2\% (Badan Pusat Statistik, 2020). Berdasarkan data KB dan Tahapan Keluarga di Kabupaten Tanggamus dari 149.242 KK yang terdaftar, sebanyak 3599 merupakan pasangan usia subur yang dibawah usia 20 tahun. Jumlah tertinggi ada di Kecamatan Ulu Belu sebanyak 560 PUS, Kota Agung Barat 517 PUS, Pematang Sawah sebanyak 444 PUS dan terendah ada di Kecamatan Limau sebanyak 1 PUS dengan usia kurang 20 tahun (Badan Pusat Statistik Kabupaten Tanggamus, 2020).

Banyak hal yang memengaruhi perilaku seseorang, menurut teori World Health Organization (WHO), seseorang itu berperilaku tertentu karena adanya empat alasan pokok yaitu pemahaman dan pertimbangan (pengetahuan, persepsi, sikap dan kepercayaan dan penilaianpenilaian seseorang terhadap objek (dalam hal ini adalah objek kesehatan), orang penting sebagai referensi (personal reference), sumber-sumber daya (resources), kebudayaan (Notoatmodjo, 2014).

Selama ini sudah banyak penelitian dan analisis tentang kehamilan yang tidak diinginkan, seperti analisis determinan kehamilan yang tidak diinginkan, pengaruh kehamilan tidak diinginkan 
terhadap berat badan bayi lahir rendah dan analisis lainnya terkait kehamilan tidak diinginkan namun belum banyak yang meneliti tentang perilaku beresiko remaja terhadap melahirkan usia anak.

Kondisi perilaku berisiko remaja Indonesia saat ini sungguh menunjukkan gejala yang makin mengkhawatirkan. Dari fakta tersebut di atas dapat disimpulkan bahwa morbiditas dan mortalitas pada remaja pada umumnya disebabkan terutama karena faktor psychosocial seperti kekerasan, kenakalan remaja, kehamilan yang tidak diinginkan, penyakit menular seksual, HIV/AIDS, penyalahgunaan obat, dan merokok. Berbagai masalah perilaku berisiko tersebut bisa saling berkaitan atau berakibat pada masalah perilaku berisiko lainnya.

Penelitian ini bertujuan untuk mempelajari masalah perilaku berisiko remaja terhadap melahirkan anak usia remaja. Dipilihnya Kabupaten Tanggamus sebagai lokasi penelitian dengan pertimbangan karena termasuk Kabupaten yang sedang dalam perkembangan pesat, baik dari segi pertumbuhan ekonomi dan teknologi informasi selain itu berdasarkan data merupakan Kabupaten dengan jumlah tertinggi pernikahan usia remaja. Sehingga peneliti tertarik untuk melakukan penelitian tentang perilaku beresiko remaja terhadap melahirkan usia anak di Kabupaten Tanggamus Tahun 2020.

\section{METODE}

Jenis penelitian kuantitatif dengan desain penelitian analitik pendekatan cross sectional. Subjek penelitian ibu nifas dan objek penelitian ini adalah pengetahuan, sikap, pendidikan, sosial ekonomi, seksual pra nikah, lingkungan fisik, kepercayaan, Peran petugas kesehatan, Peran orang tua, adat istiadat, remaja melahirkan usia anak. Pengumpulan data menggunakan kuesioner, analisis data secara univariat dengan distribusi frekuensi, analisis bivariat menggunakan uji chi square dan multivariat menggunakan uji regresi logistik. Penelitian ini telah mendapatkan laik etik dari Komite Etik
Penelitian Kesehatan Poltekkes Tanjungkarang dengan Nomor 283/KEPK-TJK/VII/2020.

\section{HASIL}

Tabel 1. Karakteristik Responden

\begin{tabular}{llrl}
\hline \multicolumn{1}{c}{ Variabel } & \multicolumn{1}{c}{ Kategori } & Jlh & \% \\
\hline \multirow{2}{*}{ Pengetahuan } & kurang baik & 114 & 46,3 \\
& baik & 132 & 53,7 \\
Pendidikan & dasar (SD-SMP) & 97 & 39,4 \\
Seksual pra & tinggi (>SMP) & 149 & 60,6 \\
nikah & ya & 78 & 31,7 \\
Lingkungan & tidak & 168 & 68,3 \\
fisik & pengaruh negatif & 77 & 31,3 \\
Sikap & negatif & 169 & 68,7 \\
& positif & 103 & 41,9 \\
Peran orang tua & pengaruh negatif & 143 & 58,1 \\
& pengaruh positif & 137 & 55,7 \\
Status ekonomi & kurang & 82 & 44,3 \\
& cukup & 164 & 66,3 \\
Sosial budaya & pengaruh negatif & 70 & 28,5 \\
Peran petugas & pengaruh positif & 176 & 71,5 \\
kesehatan & negatif & 106 & 43,1 \\
Kepercayaan & positif & 140 & 56,9 \\
Melahirkan usia & negatif & 113 & 45,9 \\
anak & ya & 133 & 54,1 \\
& tidak & 82 & 33,3 \\
& & 164 & 66,7
\end{tabular}

Berdasarkan tabel 1 dapat dilihat bahwa, dari 246 responden sebanyak $132 \quad(53,7 \%)$ responden dengan pengetahuan baik, sebanyak $149(60,6 \%)$ responden dengan pendidikan tinggi (>SMP), sebanyak $168(68,3 \%)$ responden dengan tidak melakukan seksual pra nikah, sebanyak $169(68,7 \%)$ responden dengan lingkungan fisik positif, sebanyak 143 (58,1\%) responden dengan sikap positif, sebanyak 137 $(55,7 \%)$ responden dengan peran orang tua negatif, sebanyak $164(66,7 \%)$ responden dengan status ekonomi cukup, sebanyak 176 $(71,5 \%)$ responden dengan sosial budaya positif, sebanyak $140(56,9 \%)$ responden dengan peran petugas positif,dan sebanyak $133 \quad(54,1 \%)$ responden dengan kepercayaan positif, sebanyak $164(66,7 \%)$ responden tidak melahirkan usia anak. 
Tabel 2. Hubungan Pengetahuan, Sikap, Pendidikan, Sosial Ekonomi, Seksual Pra Nikah, Lingkungan Fisik, Kepercayaan, Peran Petugas Kesehatan, Peran Orang Tua, Adat Istiadat, Remaja Melahirkan Usia Anak terhadap Ibu Melahirkan Usia Anak

\begin{tabular}{|c|c|c|c|c|c|c|c|c|c|}
\hline \multirow{3}{*}{ Variabel } & \multirow{3}{*}{ Kategori } & \multicolumn{4}{|c|}{ Melahirkan Usia anak } & \multirow{2}{*}{\multicolumn{2}{|c|}{ Total }} & \multirow{3}{*}{$\begin{array}{c}p- \\
\text { value }\end{array}$} & \multirow{3}{*}{ OR } \\
\hline & & \multicolumn{2}{|c|}{$\mathbf{Y a}$} & \multicolumn{2}{|c|}{ Tidak } & & & & \\
\hline & & $\mathbf{n}$ & $\%$ & $\mathbf{n}$ & $\%$ & $\mathbf{n}$ & $\%$ & & \\
\hline \multirow{2}{*}{ Pengetahuan } & Kurang Baik & 58 & 50,9 & 56 & 49,1 & 114 & 100,0 & 0,000 & 4,661 \\
\hline & Baik & 24 & 18,2 & 108 & 81,8 & 132 & 100,0 & & $(2,623-8,282)$ \\
\hline \multirow{2}{*}{ Sikap } & Negatif & 53 & 51,5 & 50 & 48,5 & 103 & 100,0 & 0,000 & 4,167 \\
\hline & Positif & 29 & 20,3 & 114 & 79,7 & 143 & 100,0 & & $(2,376-7,307)$ \\
\hline \multirow{2}{*}{ Pendidikan } & Dasar (SD-SMP) & 49 & 50,5 & 48 & 49,5 & 97 & 100,0 & 0,000 & 3,588 \\
\hline & Tinggi (>SMP) & 33 & 22,1 & 116 & 77,9 & 149 & 100,0 & & $(2,060-6,250)$ \\
\hline \multirow{2}{*}{ Status ekonomi } & Kurang & 41 & 50,0 & 41 & 50,0 & 82 & 100,0 & 0,000 & 3,000 \\
\hline & Cukup & 41 & 25,0 & 123 & 75,0 & 164 & 100,0 & & $(1,716-5,246)$ \\
\hline \multirow{4}{*}{$\begin{array}{l}\text { Seksual } \\
\text { pranikah } \\
\text { Lingkungan } \\
\text { fisik }\end{array}$} & Ya & 69 & 88,5 & 9 & 11,5 & 78 & 100,0 & 0,000 & 91,410 \\
\hline & Tidak & 13 & 7,7 & 155 & 92,3 & 168 & 100,0 & & $(37,314-23,931)$ \\
\hline & Pengaruh Negatif & 51 & 66,2 & 26 & 33,8 & 77 & 100,0 & 0,000 & 8,732 \\
\hline & Pengaruh Positif & 31 & 18,3 & 138 & 81,7 & 169 & 100,0 & & $(4,734-16,107)$ \\
\hline \multirow{2}{*}{ Kepercayaan } & Negatif & 58 & 51,3 & 55 & 48,7 & 113 & 100,0 & 0,000 & 4,789 \\
\hline & Positif & 24 & 18,0 & 109 & 82,0 & 133 & 100,0 & & $(2,693-8,517)$ \\
\hline \multirow{2}{*}{$\begin{array}{l}\text { Peran petugas } \\
\text { kesehatan }\end{array}$} & Negatif & 38 & 35,8 & 68 & 64,2 & 106 & 100,0 & 0,496 & 1,219 \\
\hline & Positif & 44 & 31,4 & 96 & 68,6 & 140 & 100,0 & & $(0,715-2,079)$ \\
\hline \multirow{2}{*}{ Peran orang tua } & Pengaruh Negatif & 48 & 35,0 & 89 & 65,0 & 137 & 100,0 & 0,587 & 1,190 \\
\hline & Pengaruh Positif & 34 & 31,2 & 75 & 68,8 & 109 & 100,0 & & $(0,696-2,034)$ \\
\hline \multirow{2}{*}{ Sosial budaya } & Pengaruh Negatif & 50 & 71,4 & 20 & 28,6 & 70 & 100,0 & 0,000 & 11,250 \\
\hline & Pengaruh Positif & 32 & 18,2 & 144 & 81,8 & 176 & 100,0 & & $(5,904-21,436)$ \\
\hline
\end{tabular}

Berdasarkan tabel 2 hasil uji statistik diperoleh $p$-value 0,000 yang berarti $p$-value $<\alpha$ 0,05 , maka dapat disimpulkan bahwa ada hubungan antara pengetahuan, terhadap ibu melahirkan usia anak, dengan nilai OR 4,661 yang berarti responden dengan pengetahuan kurang baik memiliki resiko sebesar 4,6 kali lebih besar melahirkan usia anak jika dibandingkan dengan responden dengan pengetahuan baik.

Hasil uji statistik diperoleh p-value 0,000 yang berarti ada hubungan antara pengetahuan, terhadap ibu melahirkan usia anak, dengan nilai OR 4,167 yang berarti responden dengan sikap negatif memiliki resiko sebesar 4,1 kali lebih besar melahirkan usia anak jika dibandingkan dengan responden dengan sikap positif.

Hasil uji statistik diperoleh $p$-value 0,000 maka dapat disimpulkan bahwa ada hubungan antara pengetahuan, terhadap ibu melahirkan usia anak, dengan nilai OR 3,588 yang berarti responden dengan pendidikan Dasar (SD-SMP) memiliki resiko sebesar 3,5 kali lebih besar melahirkan usia anak jika dibandingkan dengan responden dengan pendidikan Tinggi (>SMP)

Hasil uji statistik diperoleh $p$-value 0,000 , maka dapat disimpulkan bahwa ada hubungan antara social ekonomi, terhadap ibu melahirkan usia anak, dengan nilai OR 3,000 yang berarti responden dengan status ekonomi kurang memiliki resiko sebesar 3,000 kali lebih besar melahirkan usia anak jika dibandingkan dengan responden dengan status ekonomi cukup.

Hasil uji statistik diperoleh $p$-value 0,000 , maka dapat disimpulkan bahwa ada hubungan antara seksual pra nikah, terhadap ibu melahirkan usia anak, dengan nilai OR 91,410 yang berarti responden dengan kasus perilaku seksual pranikah memiliki risiko sebesar 91,410 kali melahirkan usia anak jika dibandingkan dengan responden kontrol melakukan seksual pra nikah.

Hasil uji statistik diperoleh $p$-value 0,000 maka dapat disimpulkan bahwa ada hubungan antara lingkungan fisik terhadap ibu melahirkan melahirkan usia anak, dengan nilai OR 8,732 yang berarti responden dengan lingkungan fisik negatif memiliki resiko sebesar 8,732 kali lebih besar melahirkan usia anak jika dibandingkan responden dengan lingkungan fisik positif.

Hasil uji statistik diperoleh $p$-value 0,000 , maka dapat disimpulkan bahwa ada hubungan antara kepercayaan terhadap ibu melahirkan usia anak, dengan nilai OR 4,789 yang berarti responden dengan kepercayaan negatif memiliki resiko sebesar 4,789 kali lebih besar melahirkan usia anak jika dibandingkan responden dengan kepercayaan positif.

Hasil uji statistik diperoleh p-value 0,496, maka dapat disimpulkan bahwa tidak ada hubungan antara peran petugas kesehatan terhadap ibu melahirkan usia anak. 
Tabel 3. Faktor Paling Dominan Berhubungan Dengan Melahirkan Usia Anak

\begin{tabular}{|c|c|c|c|c|c|c|}
\hline Variabel & p-value & OR1 & OR2 & OR2-OR1 & /OR1 & $\mathbf{x 1 0 0}$ \\
\hline \multicolumn{7}{|c|}{ Peran petugas dikeluarkan } \\
\hline Sosial budaya & ,002 & 5,479 & 5,503 & 0,024 & 0,004328 & 0,432846 \\
\hline Lingkungan fisik & 243 & 2,000 & 2,008 & 0,008 & 0,003843 & 0,384345 \\
\hline Pengetahuan &, 000 & 7,150 & 7,122 & $-0,028$ & $-0,00391$ & $-0,3907$ \\
\hline Ekonomi & 476 & 648 & 650 & 0,002 & 0,002691 & 0,26908 \\
\hline Pendidikan & 007 & 5,276 & 5,209 & $-0,067$ & $-0,01272$ & $-1,27242$ \\
\hline Peran_orang tua & 168 &, 577 &, 595 & 0,018 & 0,031731 & 3,173087 \\
\hline Seksual pranikah & 000 & 14,870 & 14,835 & $-0,035$ & $-0,00713$ & $-0,71317$ \\
\hline Sikap & 401 &, 604 & ,599 & $-0,004$ & $-0,0074$ & $-0,73978$ \\
\hline Kepercayaan & 310 & 1,779 & 1,795 & 0,016 & 0,00893 & 0,893024 \\
\hline \multicolumn{7}{|c|}{ Ekonomi Dikeluarkan } \\
\hline Sosial budaya & ,002 & 5,479 & 5,375 & $-0,104$ & $-0,01899$ & $-1,89939$ \\
\hline Lingkungan fisik & ,243 & 2,000 & 1,963 & $-0,038$ & $-0,01891$ & $-1,89124$ \\
\hline Pengetahuan & ,000 & 7,150 & 6,901 & $-0,249$ & $-0,03477$ & $-3,47703$ \\
\hline Ekonomi & 476 &, 648 & & $-0,648$ & -1 & -100 \\
\hline Pendidikan & ,007 & 5,276 & 3,843 & $-1,433$ & $-0,27157$ & $-27,1572$ \\
\hline Peran_orang tua & 168 &, 577 &, 580 & 0,003 & 0,005354 & 0,535447 \\
\hline Seksual pranikah & ,000 & 14,870 & 14,747 & $-0,122$ & $-0,02509$ & $-2,5087$ \\
\hline Sikap & 401 &, 604 & ,603 & $-0,001$ & $-0,00127$ & $-0,12677$ \\
\hline Kepercayaan & 310 & 1,779 & 1,753 & $-0,026$ & $-0,01456$ & $-1,45573$ \\
\hline \multicolumn{7}{|l|}{ Sikap dikeluarkan } \\
\hline Sosial budaya & ,002 & 5,479 & 5,315 & $-0,164$ & $-0,02992$ & $-2,99221$ \\
\hline Lingkungan fisik & 243 & 2,000 & 1,688 & $-0,313$ & $-0,15625$ & $-15,6249$ \\
\hline Pengetahuan &, 000 & 7,150 & 6,959 & $-0,191$ & $-0,02669$ & $-2,66922$ \\
\hline Ekonomi & , 476 & ,648 & 659 & 0,011 & 0,016711 & 1,671128 \\
\hline Pendidikan & 007 & 5,276 & 5,180 & $-0,097$ & $-0,0183$ & $-1,82992$ \\
\hline Peran_orang tua & 168 &, 577 &, 595 & 0,018 & 0,03105 & 3,105039 \\
\hline Seksual pranikah & 000 & 14,870 & 15,163 & 0,293 & 0,060191 & 6,019133 \\
\hline Sikap & 401 &, 604 & & $-0,604$ & -1 & -100 \\
\hline Kepercayaan & 310 & 1,779 & 1,385 & $-0,393$ & $-0,22122$ & $-22,1224$ \\
\hline \multicolumn{7}{|c|}{ Kepercayaan dikeluarkan } \\
\hline Sosial budaya & ,002 & 5,479 & 5,813 & 0,334 & 0,060959 & 6,09586 \\
\hline Lingkungan fisik & 243 & 2,000 & 2,270 & 0,270 & 0,134937 & 13,49374 \\
\hline Pengetahuan & 000 & 7,150 & 6,540 & $-0,610$ & $-0,08537$ & $-8,53726$ \\
\hline Ekonomi & ,476 &, 648 & ,676 & 0,028 & 0,042944 & 4,294435 \\
\hline Pendidikan & 007 & 5,276 & 5,606 & 0,330 & 0,062516 & 6,251586 \\
\hline Peran_orang tua & 168 &, 577 & 611 & 0,034 & 0,058938 & 5,893769 \\
\hline Seksual pranikah & 000 & 14,870 & 15,065 & 0,195 & 0,040091 & 4,009091 \\
\hline Sikap & 401 & 604 &, 830 & 0,227 & 0,375072 & 37,50716 \\
\hline Kepercayaan & ,310 & 1,779 & & $-1,779$ & -1 & -100 \\
\hline \multicolumn{7}{|c|}{ Lingkungan dikeluarkan } \\
\hline Sosial budaya & ,002 & 5,479 & 6,922 & 1,443 & 0,263303 & 26,33031 \\
\hline Lingkungan fisik & 243 & 2,000 & & $-2,000$ & -1 & -100 \\
\hline Pengetahuan &, 000 & 7,150 & 7,405 & 0,255 & 0,035699 & 3,569899 \\
\hline Ekonomi & , 476 &, 648 & 683 & 0,034 & 0,052707 & 5,270673 \\
\hline Pendidikan & 007 & 5,276 & 4,968 & $-0,308$ & $-0,05839$ & $-5,83872$ \\
\hline Peran_orang tua & 168 &, 577 &, 597 & 0,020 & 0,034773 & 3,477313 \\
\hline Seksual pranikah & 000 & 14,870 & 14,813 & $-0,057$ & $-0,01162$ & $-1,16163$ \\
\hline Sikap & ,401 & ,604 &, 760 & 0,156 & 0,25813 & 25,813 \\
\hline Kepercayaan & ,310 & 1,779 & 2,048 & 0,270 & 0,151606 & 15,16061 \\
\hline \multicolumn{7}{|c|}{ Peran Orangtua dikeluarkan } \\
\hline Sosial budaya & ,002 & 5,479 & 5,597 & 0,118 & 0,021569 & 2,156908 \\
\hline Lingkungan fisik & 243 & 2,000 & 2,008 & 0,007 & 0,003696 & 0,369552 \\
\hline Pengetahuan & 000 & 7,150 & 6,559 & $-0,591$ & $-0,08261$ & $-8,26087$ \\
\hline Ekonomi & ,476 &, 648 & ,597 & $-0,052$ & $-0,0797$ & $-7,97015$ \\
\hline Pendidikan & 007 & 5,276 & 5,365 & 0,089 & 0,016867 & 1,686741 \\
\hline Peran_orang tua & , 168 &, 577 & & $-0,577$ & -1 & -100 \\
\hline Seksual pranikah & 000 & 14,870 & 14,720 & $-0,150$ & $-0,03073$ & $-3,07251$ \\
\hline Sikap & ,401 & 604 &, 601 & $-0,003$ & $-0,00567$ & $-0,56706$ \\
\hline Kepercayaan & 310 & 1,779 & 1,690 & $-0,089$ & $-0,05004$ & $-5,0038$ \\
\hline
\end{tabular}


Berdasarkan analisis multivariat maka dalam penelitian ini dapat disimpulkan bahwa variabel prilaku seksual pranikah merupakan faktor yang paling dominan dibandingkan faktor yang lainnya yaitu variabel pengetahuan, sosial budaya,pendidikan, lingkungan fisik. ekonomi, sikap dan kepercayaan.

\section{PEMBAHASAN}

\section{Pengetahuan terhadap Ibu Melahirkan Usia Anak}

Hasil uji statistik diperoleh ada hubungan antara pengetahuan, terhadap ibu melahirkan usia anak di Kabupaten Tanggamus Tahun 2020, dengan pengetahuan kurang baik memiliki resiko sebesar 4,6 kali lebih besar melahirkan usia anak jika dibandingkan dengan responden dengan pengetahuan baik.

Pengetahuan merupakan hasil dari tahu setelah orang melakukan penginderaan terhadap objek tertentu. Penginderaan terjadi melalui panca indera manusia, yakni indera penglihatan, pendengaran, penciuman, rasa dan raba. Sebagaian besar pengetahuan manusia diperoleh melalui mata dan telinga (Budiman, 2013).

Tingkat pendidikan seseorang memengaruhi pengetahuan, termasuk juga perilaku seseorang akan pola hidup untuk sikap berperan serta dalam pembangunan. Pada umumnya semakin tinggi pendidikan seseorang maka semakin mudah menerima informasi (Notoatmodjo, 2012).

Penelitian Banepaa (2017) didapatkan jumlah usia menikah terbanyak pada usia 18-20 yaitu 57 responden (92\%), jumlah usia pertama melakukan hubungan seksual terbanyak pada usia 18-20 yaitu 39 responden $(62,9 \%)$, jumlah responden terbanyak pada status pendidikan SMA yaitu 47 responden $(75,9 \%)$, responden terbanyak memiliki pengetahuan baik sebanyak 47 orang $(75,8 \%)$, responden terbanyak memiliki perilaku beresiko sebanyak 33 orang $(53,2 \%)$, responden terbanyak tidak mengonsumsi zat kimia sebanyak 32 orang $(51,7 \%)$, jumlah responden terbanyak pada responden yang tidak ikut serta dalam penggunaan kontrasepsi yaitu 40 responden $(64,6 \%)$.

Menurut peneliti pengetahuan adalah salah satu faktor yang menentukan, responden dalam menentukan sikap di kehidupanya, ketika remaja usia anak mengetahui dampak besar dari kehamilan usia anak, hingga persalinan dan nifas, maka wanita usia anak akan mencegah terjadinya kehamilan usia anak. Selain itu pengetahuan merupakan faktor yang mendukung perilaku ibu dalam deteksi dini komplikasi kehamilan dan persalinan. Sehingga semakin kurang baik pengetahuan maka semakin tinggi kejadian komplikasi kehamilan. Upaya deteksi yang rendah disebabkan karena tingkat pengetahuan yang rendah. Jika dikaitkan dengan kejadian komplikasi persalinan. Timbulnya kasus komplikasi persalinan ini akibat kurangnya praktik ibu dalam pemeriksaan kehamilan dan upaya diagnosis dini adanya komplikasi yang akan terjadi, sehingga ibu mengalami komplikasi yang tak terduga sebelumnya.

\section{Sikap terhadap Ibu Melahirkan Usia Anak}

Ada hubungan antara sikap terhadap ibu melahirkan usia anak di Kabupaten Tanggamus Tahun 2020, dengan sikap negatif memiliki resiko sebesar 4,167 kali lebih besar melahirkan usia anak jika dibandingkan dengan responden dengan sikap positif.

Notoatmodjo (2014) mengidentifikasikan sikap sebagai kesediaan untuk bereaksi (disposition to react) secara positif (favorably) atau secara negatif (unfavorably) terhadap objekobjek tertentu. Sikap sebagai organisasi yang bersifat menetap dari proses motivasional, emosional, perseptual, dan kognitif mengenai aspek dunia individu.

Hasil penelitian Yuniarti, dkk. (2011) diketahui bahwa remaja putri di Desa Ciwareng setengahnya $(44,9 \%)$ kurang mengetahui tentang kehamilan usia anak dan sebagian besar $(52,6 \%)$ bersikap negatif terhadap kehamilan usia anak. Hasil uji statistik diperoleh bahwa ada hubungan yang signifikan antara pengetahuan dengan sikap remaja putri tentang kehamilan usia anak ( $p$ value $=0,0001$ ).

Sikap merupakan kesediaan atau kesiapan untuk berperilaku (Notoadmodjo, 2014). Sikap dan norma sosial merupakan bagian penting dalam kehidupan remaja dalam mengambil keputusan untuk berperilaku berisiko. Hasil penelitian menunjukkan bahwa mayoritas responden sudah memiliki sikap yang baik terhadap perilaku pencegahan terhadap terjadinya kehamilan anak. Selain pernyataan bercium bibir (16\%) responden setuju, kurang dari 5\% respondent menjawab sangat setuju dan setuju terhadap pernyataan perilaku risiko tinggi terhadap kehamilan usia anak seperti pernyataan meraba-raba dada, melakukan petting, melakukan anal seks, melakukan oral seks, melakukan hubungan seksual sebelum menikah dan melakukan aborsi untuk menutupi kehamilan. 
Dampak kehamilan usia anak meliputi seluruh aspek kehidupan remaja seperti memengaruhi aspek kesehatan, fisik, psikologis dan sosial. Keselamatan dan kesehatan remaja dan anak yang dikandungnya berada dalam risiko sendiri yang disebabkan karena otot-otot Rahim masih lemah, belum berkembang sempurna, dan secara mental juga belum dewasa. Banyak remaja yang melakukan pernikahan terpaksa, yang terkadang berakibat pada perceraian dan aborsi tidak aman (Sarwono, 2013).

Menurut peneliti, sikap adalah tindakan seseorang dalam melakukan sesuatu, ketika seseorang memiliki pengetahuan, dan persepsi yang bagus terhadap suatu masalah, maka dia akan bersikap positif atau baik, tetapi jika seseorang dominan memiliki atau lebih berpersepsi positif pada hal yang salah maka seseorang itu akan tetap melakukannya. Maka seseorang akan bersikap melahirkan usia anak walaupun mengetahui dampaknya. Sikap dipengaruhi banyak hal, melahirkan usia anak juga memiliki banyak faktor penyebab. Selain itu faktor emosi dalam diri individu juga dapat memengaruhi sikap dari seseorang. Tanggapan yang ditunjukkan seseorang dan merupakan bentuk dari pertahanan ego juga dapat mencerminkan sikap seseorang terhadap sesuatu, namun terkadang sikap ini hanya berlangsung sementara. Emosi yang ditunjukkan oleh responden dapat menentukan pilihan sikap, sehingga pengetahuan yang kurang juga bisa menunjukkan sikap yang sangat positif.

Pendidikan terhadap Ibu Melahirkan Usia Anak

Hasil diperoleh bahwa ada hubungan antara pendidikan terhadap ibu melahirkan usia anak di Kabupaten Tanggamus Tahun 2020, dimana responden dengan pendidikan dasar memiliki resiko sebesar 3,588 kali lebih besar melahirkan usia anak jika dibandingkan dengan responden pendidikan tinggi

Pendidikan adalah suatu proses belajar yang berarti didalam pendidikan itu terjadi proses pertumbuhan, perkembangan atau berubah kearah yang lebih dewasa, lebih baik dan matang pada diri individu, kelompok atau masyarakat. Pendidikan saat ini merupakan kebutuhan primer setiap manusia. Karenanya, pendidikan tidak boleh dianggap sepele karena pendidikan akan meningkatkan harkat dan martabat manusia itu sendiri. Pendidikan dalam kehidupan manusia merupakan sebuah proses yang harus dilakukan sepanjang hayat. Pada saat ini pendidikan bukan hanya merupakan suatu proses pembelajaran dalam masyarakat, tetapi sudah berkembang menjadi pusat atau narasumber dari segala pengetahuan (Notoadmotjo, 2014).

Menurut penelitian Realita \& Meiranny (2018) terdapat pengaruh pendidikan terhadap kehamilan remaja dan tidak terdapat pengaruh pendapatan terhadap kehamilan remaja. Begitu pula dengan hasil penelitian Kurniawati (2016) menunjukkan bahwa ada hubungan yang signifikan antara tingkat pendidikan dengan usia perkawinan pertama wanita.

Pendidikan seks yang kurang di kebanyakan negara menyebabkan beberapa gadis tidak tahu cara menghindari hamil. Mereka mungkin merasa terlalu malu untuk mencari layanan kontrasepsi. Kontrasepsi mungkin terlalu mahal atau tidak banyak atau secara hukum tidak tersedia. Bahkan ketika kontrasepsi yang banyak tersedia, remaja perempuan yang aktif secara seksual cenderung menggunakannya daripada orang dewasa (Realita \& Meiranny, 2018).

Mereka yang melakukan pernikahan dini adalah mereka yang memiliki pendidikan SD, SLTP dan SLTA. Semakin rendah tingkat pendidikan, semakin mendorong pernikahan dini. Rendahnya tingkat pendidikan dan pengetahuan memengaruhi pola fikir terbatas yang akan berdampak pada perilaku individu (Syafangah, 2017).

Sejalan dengan penelitian sebelumnya yang mengatakan bahwa orang yang berpendidikan rendah cenderung melakukan pernikahan dini disebabkan rendahnya pengetahuan mereka terkait pernikahan dini (Realita \& Meiranny, 2018). Menurut Kumalasari dan Iwan (2012) dampak dari pernikahan dini adalah alat reproduksi belum siap menerima kehamilan sehingga dapat menimbulkan beberapa komplikasi, banyaknya kasus menikah dini berbanding lurus dengantingginya angka perceraian, dan psikologi yang belum matang, sehingga cenderung labil dan emosi.

Menurut peneliti tingkat pendidikan merupakan salah satu faktor internal yang memengaruhi melahirkan usia anak. Tingkat pendidikan seseorang memengaruhi cara pandang dan berfikir seseorang maka akan semakin banyak pengetahuan yang didapatkan, sehingga dengan pengetahuan yang lebih banyak diharapkan dalam pengambilan keputusan untuk melakukan pernikahan akan semakin logis. Tingkat pendidikan yang rendah dapat memengaruhi kehidupan seorang wanita termasuk dengan kehidupan berumahtangga. Pengetahuan yang rendah menyebabkan seseorang kurang memiliki pengetahuan dan kesiapan dalam menghadapi pernikahan, sehingga 
dalam pengambilan keputusan untuk menikah tidak banyak memiliki pertimbangan.

\section{Hubungan Status Ekonomi terhadap Melahirkan Usia Anak}

Ada hubungan antara sosial ekonomi terhadap ibu melahirkan usia anak di Kabupaten Tanggamus Tahun 2020, dengan status ekonomi kurang memiliki resiko sebesar 3,000 kali lebih besar melahirkan usia anak jika dibandingkan dengan responden dengan status ekonomi cukup.

Pengaruh sosial ekonomi merupakan hal yang cukup berpengaruh dalam penggunaan fasilitas kesehatan, walaupun secara tidak langsung. Pendapatan yang rendah akan menyulitkan seorang untuk memenuhi kebutuhan kesehatan terutama obat-obatan yang akan dibeli. Hal ini pada akhirnya akan menyebabkan sesorang mengabaikan kesehatan dirinya.

Penelitian Budiman (2017), gambaran umur sebagian besar (40\%) umur ibu hamil <21 tahun, paritas (54\%) multipara, tingkat pendidikan (44\%) adalah SMA, status pekerjaan (76\%) Ibu Rumah Tangga, dan status sosial ekonomi $(76 \%)$ berpendapatan di bawah upah minimum pekerja. Dari analisis Chi Square terdapat hubungan yang signifikan antara tingkat pendidikan dengan paritas, tidak terdapat hubungan yang signifikan antara pekerjaan dengan paritas, dan tidak terdapat hubungan yang siginifikan antara status ekonomi dengan paritas.

Hasil penelitian Kurniawati (2016) menunjukkan bahwa ada hubungan yang signifikan antara tingkat pendapatan dengan usia perkawinan pertama wanita, dan tidak ada hubungan yang signifikan antara status pekerjaan dengan usia perkawinan pertama wanita.

Secara sosial ekonomi, pernikahan remaja menjadi salah satu gejala yang menunjukkan rendahnya status wanita. Pada beberapa kasus, pernikahan remaja berkaitan dengan terputusnya kelanjutan sekolah wanita yang berakibat pada tingkat pendidikan wanita menjadi rendah. Pendidikan yang rendah akan merugikan posisi ekonomi wanita dan rendahnya tingkat partisipasi kerja wanita.

Hasil penelitian ini menunjukkan ada pengaruh sosial ekonomi terhadap kejadian melahirkan usia anak berkaitan dengan tradisi dan budaya, dan alasan ekonomi. Harapan mencapai keamanan sosial dan finansial setelah menikah menyebabkan banyak orang tua mendorong anaknya untuk menikah di usia anak. Keputusan remaja putri untuk menikah seringkali dibuat oleh orang tua atau masyarakat. Pada umumnya remaja putri di pedesaan dengan sosial ekonomi rendah setelah putus sekolah mereka merantau ke kota untuk mencari pekerjaan sebagai buruh atau pembantu rumah tangga. Pendidikan rendah, keterampilan kurang menyebabkan mereka hanya mendapatkan pekerjaan kasar. Dengan menikah di usia anak, mereka dan orang tua percaya akan membantu melengkapi fungsi sosial, perlindungan dan menjamin stabilitas ekonomi untuk anak perempuan dan keluarga.

\section{Hubungan Seksual Pra Nikah dengan Melahirkan Usia Anak}

Hasil uji statistik diperoleh bahwa ada hubungan antara seksual pra nikah terhadap ibu melahirkan usia anak dengan perilaku kasus seksual pranikah memiliki risiko sebesar 19,410 kali melahirkan usia anak jika dibandingkan dengan responden kontrol tidak melakukan seksual pra nikah

Perilaku seksual adalah segala tingkah laku yang didorong oleh hasrat seksual, baik dengan lawan jenisnya maupun dengan sesama jenis. Bentuk-bentuk tingkah laku ini bisa bermacammacam, mulai dari perasaan tertarik sampai tingkah laku berkencan, bercumbu dan bersenggama. Objek seksualnya bisa berupa orang lain, orang dalam khayalan atau diri sendiri (Sarwono, 2013).

Penelitian yang dilakukan oleh Dewi (2012) mengungkapkan bahwa separuh remaja di Kelurahan Pasir Gunung Selatan Kota Depok berperilaku seksual berisiko $(56,8 \%)$ yaitu pegangan tangan, berpelukan, masturbasi, masturbasi berat, ciuman bibir, saling meraba bagian sensitif, melakukan petting, dan hubungan seks. Selain itu juga disebutkan bahwa remaja dengan frekuensi berpacaran lebih dari satu kali memiliki peluang berperilaku seksual berisiko sebanyak dua kali daripada remaja dengan frekuensi berpacaran satu kali.

Menurut peneliti, frekuensi pacaran yang sering mendorong remaja untuk mempraktekan hubungan seksual pranikah yang berdampak kehamilan pranikah karena telah terjadi perubahan pandangan terhadap pacaran bahwa zaman sekarang telah terjadi perubahan pandangan dan perilaku seksual di masyarakat khususnya remaja yang tidak lagi menganggap pacaran sebagai ajang untuk saling mengenal lawan jenis tetapi untuk belajar melakukan aktivitas seksual dengan lawan jenis. Aktivitas seksual yang mereka lakukan dimulai dari memandang tubuh, berpegangan tangan, berciuman sambil berpelukan, meraba tubuh pasangan, saling mengelus daerah erogen sampai kepada yang paling berisiko yaitu berhubungan 
seksual. Berhubungan seksual sangat dekat urutannya dengan kejadian kehamilan pada wanita usia dini, dengan kejadiannya kehamilan maka akan terjadi persalinan usia anak. Maka pada wanita usia dini yang melakukan hubungan seksual sebelum menikah maka kejadian melahirkan usia anak akan lebih tinggi di bandingkan dengan faktor lain seperti pengetahuan dan pendidikan.

\section{Hubungan Lingkungan Fisik terhadap Ibu Melahirkan Usia anak}

Hasil uji statistik diperoleh bahwa ada hubungan antara lingkungan fisik terhadap ibu melahirkan usia anak, dengan nilai OR 8,732 yang berarti responden dengan lingkungan fisik negatif memiliki resiko sebesar 8,732 kali lebih besar melahirkan usia anak jika dibandingkan responden dengan lingkungan fisik positif

Faktor luar seperti pergaulan bebas tanpa kendali orang tua menyebabkan remaja merasa bebas untuk melakukan apa saja yang diinginkan serta perkembangan teknologi media komunikasi yang semakin canggih yang memperbesar kemungkinan remaja mengakses apa saja yang termasuk hal-hal negatif (Kusmiran, 2012.

Tidak bisa dipungkiri, masih ada pula perkawinan usia dini yang terjadi karena hamil di masa pacaran. Faktor lain yang juga memengaruhi kejadian pernikahan dini adalah faktor lingkungan. Hasyim dikutip Jannah (2012) menyebutkan bahwa dalam konteks Indonesia, pernikahan lebih condong diartikan sebagai kewajiban sosial dari pada manifestasi kehendak bebas setiap individu. Suhardi (2012) menjelaskan bahwa dalam masyarakat yang pola hubungannya bersifat tradisional, pernikahan dipersepsikan sebagai suatu "keharusan sosial" yang merupakan bagian dari warisan tradisi dan dianggap sakral. Cara pandang tradisional terhadap perkawinan sebagai kewajiban sosial, tampaknya memiliki kontribusi yang cukup besar terhadap fenomena pernikahan dini yang terjadi di Indonesia.

Sejalan dengan penelitian Sulistianingsih (2010) diketahui bahwa $70 \%$ responden menunjukkan lingkungan pergaulan remaja mendukung, sedangkan $12 \%$ berpendapat bahwa lingkungan pergaulan sangat mendukung. Penelitian Dumilah, dkk. (2017) menunjukkan bahwa remaja yang memiliki teman sebaya tidak mendukung perkawinan dibawah umur berpeluang memiliki persepsi baik 2,632 kali dan remaja yang memiliki lingkungan keluarga tidak mendukung perkawinan dibawah umur berpeluang memiliki persepsi baik 2,524 kali dibandingkan remaja yang memiliki lingkungan keluarga mendukung perkawinan dibawah umur.

Penelitian Prawardani (2015) menunjukkan hasil bahwa ada hubungan yang signifikan antara pergaulan, dukungan orang tua, dan media massa dengan kehamilan pada remaja di Wilayah Kerja Puskesmas Serupa Indah Pakuan Ratu Kabupaten Way Kanan Tahun 2014. Menurut Mayse (2017), penyebab kehamilan di usia remaja dapat terjadi karena faktor lingkungan, pergaulan, ekonomi, dan pola asuh orang tua. Pergaulan dalam hal ini adalah pergaulan yang kurang baik, yaitu melakukan sex pranikah yang dapat mengakibatkan kehamilan sehingga harus menikah di usia anak.

Menurut peneliti bahwa lingkungan fisik adalah keadaan di sekitar seseorang yang dapat memengaruhi kebiasaan. Pada wanita usia dini yang memiliki lingkungan dengan seksual aktif kemudian kebiasaan melahirkan usia anak, persepsi menginginkan menjadi ibu muda dengan melakukan pernikahan muda, hal ini juga akan memengaruhi seseorang didalamnya untuk mengikutinya. Maka peran orang tua dalam lingkungan remaja ini perlu lebih diperhatikan kembali serta perlu melakukan monitoring agar remaja tidak terjebak dalam lingkungan yang salah.

\section{Hubungan Kepercayaan terhadap Ibu Melahirkan Usia anak}

Ada hubungan antara kepercayaan terhadap ibu melahirkan usia anak di Kabupaten Tanggamus Tahun 2020, dengan nilai OR 4,789 yang berarti responden dengan kepercayaan negatif memiliki resiko sebesar 4,789 kali lebih besar melahirkan usia anak jika dibandingkan responden dengan kepercayaan positif. Hal ini sejalan dengan penelitian Prawardani (2015), yang menunjukkan bahwa ada hubungan yang signifikan antara ketaatan beribadah dengan kehamilan pada remaja di Wilayah Kerja Puskesmas Serupa Indah Pakuan Ratu Kabupaten Way Kanan Tahun 2014.

Menurut penelitian Kosati (2019) didapatkan hasil bahwa terdapat hubungan signifikan antara peran orang tua, teman sebaya dan relijiusitas dengan perilaku seksual berisiko dengan nilai $p$-value 0,000 . Sedangkan pada penelitian Juariah (2019) menunjukkan bahwa masyarakat Desa Karangsari masih mengikuti kebiasaan yang harus dilakukan ibu pada saat hamil dan juga pantangan/larangan yang harus dihindari oleh ibu hamil, dengan keyakinan jika pantangan itu dilanggar akan mengakibatkan hal buruk pada ibu dan bayi yang dikandungnya. 
Masyarakat Desa Karangsari juga masih mempertahankan adat upacara opat bulanan dan nujuh bulanan walaupun dalam pelaksanaannya disesuaikan dengan kemampuan ibu hamil dan keluarganya. Suami terlibat dalam kehamilan istrinya dengan mengikuti keharusan dan pantangan dan meyakini akan ada akibat buruk jika tidak mengikuti kebiasaan tersebut. Tenaga kesehatan dan maraji pemanfaatannya saling berdampingan, walaupun maraji memiliki otoritas terutama dalam ritual seremonial.

Menurut peneliti bahwa kepercayaan seseorang terhadap praktisi sesuatu lebih banyak didapat dari pengalaman seseorang. Hal ini berhubungan dengan sosial dan budaya yang ada dan diyakini oleh seseorang, seperti menikah muda, kemudian memiliki anak akan menjadi ibu muda yang akan sama tumbuhnya dengan anak, yang dapat bermain lama dengan anak karena masih muda anak sudah besar, tren mama muda ini juga dapat diyakini seseorang untuk melahirkan usia anak tanpa melihat dampak yang dapat terjadi.

\section{Hubungan Peran Petugas Kesehatan terhadap Ibu Melahirkan Usia anak}

Hasil uji statistik didapatkan bahwa tidak ada hubungan antara peran petugas kesehatan terhadap ibu melahirkan usia anak di Kabupaten Tanggamus Tahun 2020. Berbeda dengan hasil penelitian Ramadani (2017) mendapatkan sebanyak 52,9\% responden kurang merasakan peran dari tenaga kesehatan, dengan nilai $p$ value $=0,032$, tenaga kesehatan berperan dalam kehamilan remaja.

Menurut peneliti petugas kesehatan memiliki tugas di masyarakat yakni menjadi pendidik, termasuk pada remaja, dengan pendidikan kesehatan remproduksi yang baik, serta pendidikan seksual yang tidak boleh dilakukan. Peran petugas kesehatan sangat dibutuhkan untuk mengurangi risiko yang terjadi pada kehamilan usia remaja. Petugas kesehatan selaku edukator berperan dalam melaksanakan bimbingan atau penyuluhan, pendidikan pada klien, keluarga, masyarakat, dan tenaga kesehatan termasuk siswa bidan/keperawatan tentang penanggulangan masalah kesehatan, khususnya yang berhubungan dengan kesehatan reproduksi termasuk mengenai kehamilan usia remaja. Peran penyuluhan petugas kesehatan dilaksanakan dengan proses pemberian bantuan yang dilakukan melalui wawancara petugas kesehatan kepada individu yang sedang mengalami masalah kesehatan.

\section{Hubungan Peran Orang Tua terhadap Ibu Melahirkan Usia anak}

Hasil penelitian menunjukkan bahwa tidak ada hubungan antara peran orang tua terhadap ibu melahirkan usia anak di Kabupaten Tanggamus Tahun 2020. Hal ini berbeda dengan penelitian Kosati (2019) bahwa ada hubungan signifikan antara peran orang tua dengan perilaku seksual berisiko. Sejalan pula dengan hasil penelitian Prawardani (2015), bahwa ada hubungan yang signifikan antara dukungan orang tua ( $p$-value $0,004)$ dengan kehamilan pada remaja di Wilayah Kerja Puskesmas Serupa Indah Pakuan Ratu Kabupaten Way Kanan Tahun 2014. Hasil penelitian Ramadani (2017) juga mengungkapkan adanya hubungan dukungan keluarga (nilai $p$ value $=0,025$ ) dengan kehamilan usia remaja.

Dukungan keluarga menurut Friedman (2014) adalah sikap, tindakan penerimaan keluarga terhadap anggota keluarganya, berupa dukungan informasional, dukungan penilaian, dukungan instrumental dan dukungan emosional. Jadi dukunan keluarga adalah suatu bentuk hubungan interpersonal yang meliputi sikap, tindakan dan penerimaan terhadap anggota keluarga, sehingga anggota keluarga merasa ada yang memperhatikannya. Jadi dukungan sosial keluarga mengacu kepada dukungan-dukungan sosial yang dipandang oleh anggota keluarga sebagai sesuatu yang dapat diakses atau diadakan untuk keluarga yang selalu siap memberikan pertolongan dan bantuan jika diperlukan. Keluarga berfungsi sebagai sistem pendukung bagi anggotanya. Anggota keluarga memandang bahwa orang yang bersifat mendukung, selalu siap memberikan pertolongan dan bantuan jika diperlukan.

Dukungan keluarga didefinisikan oleh Gottlieb dalam Padila (2012) yaitu informasi verbal, sasaran, bantuan yang nyata atau tingkah laku yang diberikan oleh orang-orang yang akrab dengan subjek didalam lingkungan sosialnya atau yang berupa kehadiran dan hal yang dapat memberikan keuntungan emosional atau pengaruh pada tingkah laku penerimaannya. Dalam hal ini orang yang merasa memperoleh dukungan sosial, secara emosional merasa lega diperhatikan, mendapat saran atau kesan yang menyenangkan pada dirinya (Padila, 2012).

Santrock (2009) mengatakan yang dimaksud dengan pola asuh adalah cara atau metode pengasuhan yang digunakan oleh orang tua agar anak-anaknya dapat tumbuh menjadi individuindividu yang dewasa secara sosial. Cara orang tua dalam mengasuh anak akan turut menentukan perilaku anakanaknya kelak. bahwa 
terdapat empat tipe pola asuh orangtua, yaitu: 1) pola asuh demokratis, 2) pola asuh otoriter, 3) pola asuh permisif, dan 4) pola asuh penelantar. Pola asuh demokratis adalah pola asuh yang memprioritaskan kepentingan anak tetapi orangtua tetap dapat mengendalikan anak dengan tegas.

Menurut peneliti orang tua yang mempunyai peran yang baik dalam memberikan pendidikan seksualitas terhadap putra-putrinya maka cenderung putra-putrinya akan mempunyai sikap yang baik, sehingga akan terhindar dari perilaku seks yang menyimpang dan tidak bertanggungjawab seperti seks bebas. Sedangkan orang tua yang mempunyai peran yang kurang baik terhadap pendidikan seksualitas maka akan berpengaruh yang tidak baik atau buruk pada remaja yang dapat menimbulkan remaja tersebut akan berperilaku yang menyimpang dan terjerumus dalam pergaulan bebas seperti seks bebas dan hamil di usia anak serta melahirkan usia anak.

\section{Hubungan Sosial Budaya terhadap Ibu Melahirkan Usia anak}

Ada hubungan antara sosial budaya terhadap ibu melahirkan usia anak di Kabupaten Tanggamus Tahun 2020, dengan nilai OR 11,250 yang berarti responden dengan sosial budaya negatif memiliki resiko sebesar 11,250 kali lebih besar melahirkan usia anak jika dibandingkan responden dengan social budaya positif.

Penelitian Juariah (2019) menunjukkan bahwa masyarakat Desa Karangsari masih mengikuti kebiasaan yang harus dilakukan ibu pada saat hamil dan juga pantangan/larangan yang harus dihindari oleh ibu hamil, dengan keyakinan jika pantangan itu dilanggar akan mengakibatkan hal buruk pada ibu dan bayi yang dikandungnya. Masyarakat Desa Karangsari juga masih mempertahankan adat upacara opat bulanan dan nujuh bulanan walaupun dalam pelaksanaannya disesuaikan dengan kemampuan ibu hamil dan keluarganya. Suami terlibat dalam kehamilan istrinya dengan mengikuti keharusan dan pantangan dan meyakini akan ada akibat buruk jika tidak mengikuti kebiasaan tersebut. Tenaga kesehatan dan maraji pemanfaatannya saling berdampingan, walaupun maraji memiliki otoritas terutama dalam ritual seremonial.

Menurut penelitian Juariah (2019), budaya pada masa kehamilan dan persalinan di sebagian daerah telah terjadi pergeseran namun di sebagian lain masih dipertahankan. Hal ini seperti yang dijelaskan oleh O’Neil (2006, dalam Juariah, 2019) bahwa semua budaya yang diwariskan cenderung untuk berubah tetapi adakalanya juga dipertahankan. Ada proses dinamis yang mendukung diterimanya hal-hal dan ide-ide baru dan adajuga yang mendukung untuk mempertahankan kestabilanbudaya yang ada. Hiller (2003, dalam Juariah, 2019) menyatakan bahwa ketika perubahan terjadi, maka terjadi destruksi nilai-nilai tradisional, kepercayaan, peran dan tanggungjawab,pendidikan, keluarga dan lain-lain yang hampir simultan dengan proses konstruksi cara baru sebagai pengaruh dari perubahan sosial. Nilai dan ritual yang baru ini menggantikan nilai dan ritual yang lama. Namun di sebagian masyarakat adakalanya terjadi kompromi yang mana nilai dan ritual baru dijalankan dengan tanpa menghilangkan nilai dan ritual lama.

Menurut peneliti, adat dan budaya merupakan faktor seseorang berprilaku, kebiasaat yang ada di daerah tersebut seperti anak usia 18 tahun atau jika sudah menstruasi adalah sudah besar yang di perbolehkan menikah akan membuat banyak wanita melahirkan pada usia anak. Kondisi sosial budaya (adat istiadat) dan kondisi lingkungan (kondisi geografis) berpengaruh terhadap kesehatan reproduksi. Situasi budaya dalam hal ini adat istiadat saat ini memang tidak kondusif untuk help seeking behavior dalam masalah kesehatan reproduksi di Indonesia Hal ini dikemukakan berdasarkan realita, bahwa masyarakat Indonesia pada umumnya sudah terbiasa menganggap bahwa kehamilan merupakan suatu hal yang wajar yang tidak memerlukan antenal care. Hal ini tentu berkaitan pula tentang pengetahuan dan pemahaman masyarakat tentang pentingnya antenal care dan pemeliharaan kesehatan reproduksi lainnya juga melahirkan yang sehat dan usia yang baik

\section{SIMPULAN}

Ada hubungan pengetahuan, sikap, status ekonomi, seksual pra nikah, lingkungan fisik, kepercayaan, adat istiadat terhadap prilaku melahirkan usia anak. Tidak ada hubungan peran petugas kesehatan, peran orang tua terhadap perilaku melahirkan usia anak. Faktor dominan terhadap melahirkan usia anak di Kabupaten Tanggamus Tahun 2020 adalah seksual pranikah.

Oleh karena itu diangap perlu meningkatkan program posyandu pada remaja yang ada di Puskesmas dalam peningkatan kesehatan reproduksi dan pencegahan perilaku seksual pranikah. Meningkatkan pendidikan secara informal, seperti mengikuti penyuluhan- 
penyuluhan yang diadakan oleh petugas kesehatan. Mengunjungi posyandu remaja yang diselenggarakan oleh pihak Puskesmas dalam meningkatkan pengetahuan terhadap bahaya atau

\section{DAFTAR PUSTAKA}

Aprianti, A., Shaluhiyah, Z., \& Suryoputro, A. (2018). Fenomena Pernikahan Dini Membuat Orang Tua dan Remaja Tidak Takut Mengalami Kehamilan Tidak Diinginkan. Jurnal Promosi Kesehatan Indonesia, $\quad 13(1), \quad 61$. https://doi.org/10.14710/jpki.13.1.61-73

Badan Pusat Statistik. (2020). Pencegahan perkawinan anak percepatan yang tidak bisa di tunda. Badan Pusat Statistik, 0-44.

Badan Pusat Statistik Kabupaten Tanggamus. (2020). Jumlah Pasangan Usia Subur dan Peserta KB Aktif Menurut Kecamatan di Kabupaten Tanggamus. Tanggamus.

Banepaa, A., Meo, M. L. N., \& Gatum, A. M. (2017). Gambaran Faktor-faktor yang Mempengaruhi Kehamilan Remaja Usia 14-19 Tahun di Kelurahan Bakunase Wilayah Kerja Puskesmas Bakunase Kota Kupang. CHMK Nursing Scientific Journal, 1(2), 1-9.

Budiman, E., Kundre, R., \& Lolong, J. (2017). Hubungan Tingkat Pendidikan, Pekerjaan, Status Ekonomi Dengan Paritas Di Puskesmas Bahu Manado. Jurnal Keperawatan UNSRAT, 5(1), 110831.

Budiman. (2013). Kapita selekta Pengetahuan dan sikap untuk penelitian kesehatan. Jakarta: Penerbit Salemba Medika.

Dewi, A. P. 2012. Hubungan Karakteristik Remaja, Peran Teman Sebaya dan Paparan Pornografi Dengan Perilaku Seksual Remaja di Kelurahan Pasir Gunung Selatan Depok. [Tesis]. Depok: Fakultas Ilmu Keperawatan, Universitas Indonesia.

Dini, L. I., Riono, P., \& Sulistiyowati, N. (2016). Pengaruh Status Kehamilan Tidak Diinginkan Terhadap Perilaku Ibu Selama Kehamilan dan Setelah Kelahiran di Indonesia (Analisis Data SDKI 2012). Jurnal Kesehatan Reproduksi, 7(2), 119-133.

Dumilah, Pratiwi Retno Ayu, Sri Sumarmi. (2017). Hubungan Anemia Dengan Prestasi Belajar Siswi di SMP Unggulan Bina Insani. Jurnal Amerta Nutrition, hal 331340. Universitas Airlangga

Friedman, M. M., Bowden, V. R., \& Jones, E. G. (2014). Buku Ajar Keperawatan Keluarga dampak dari perilaku seksual pranikah serta bahaya dari kehamilan di usia anak atau usia $<20$ tahun.

(Riset, teori, dan praktik). Edisi 5. Jakarta : EGC

Hidayati, K., \& Farid. (2016). Konsep Diri, Adversity Quotient dan Penyesuaian Diri pada Remaja. Persona: Jurnal Psikologi Indonesia, 5(02), 137-144. https://doi.org/10.30996/persona.v5i02.730

Izugbara, C., \& Egesa, C. (2014). The Management of Unwanted Pregnancy Among Women in Nairobi, Kenya. International Journal of Sexual Health, 26(2),

100-112. https://doi.org/10.1080/19317611.2013.831 965

Jannah, U. S. F. (2012). Pernikahan dini dan implikasinya terhadap kehidupan keluarga pada masyarakat Madura (perspektif hukum dan gender). EGALITA.

Juariah, J. (2019). PERSEPSI ORANG DEWASA TERHADAP KESEHATAN REPRODUKSI REMAJA AWAL (STUDI KASUS DI JALUR PANTAI UTARA, JAWA BARAT). Kesmas Indonesia: Jurnal Ilmiah Kesehatan Masyarakat, 11(2), 150-165.

Kosati, T. W. (2019). HUBUNGAN ANTARA PERAN ORANG TUA, TEMAN SEBAYA DAN RELIGIUSITAS DENGAN PERILAKU SEKSUAL BERISIKO PADA REMAJA AWAL DI SMP NEGERI "A" SURABAYA. [Skripsi]. Surabaya: Fakultas Keperawatan, Universitas Airlangga.

Kumalasari, I. Iwan, A. (2012). Kesehatan Reproduksi untuk Kebidanan dan Keperawatan. Jakarta: Salemba Medika.

Kurniawati, L., Nurrochmah, S., \& Katmawanti, S. (2016). Hubungan antara tingkat pendidikan, status pekerjaan dan tingkat pendapatan dengan usia perkawinan pertama wanita di Kelurahan Kotalama Kecamatan Kedungkandang Kota Malang. Preventia: The Indonesian Journal of Public Health, 1(2), 210-219.

Kusmiran, E. (2012). Kesehatan Repsroduksi Remaja Dan Wanita (J. Selatan, ed.). Salemba Medika.

Marston, C., \& Cleland, J. (2003). Do unintended pregnancies carried to term lead to adverse 
outcomes for mother and child? An assessment in five developing countries. Population Studies, 57(1), 77-93. https://doi.org/10.1080/0032472032000061 749

Mayse M.L. (2017). Non malignant pleural effusions. In: Fishman A.P, editor. Fishman's pulmonary.

Notoatmodjo, S. (2012). Metodologi Penelitian. Jakarta: Rineka Cipta.

Notoatmodjo, S. (2014). Ilmu Perilaku Kesehatan. Jakarta: PT Rineka Cipta.

Nourollahpour Shiadeh, M., Kariman, N., Bakhtiari, M., Mansouri, S., \& Mehravar, S. (2016). Unwanted Pregnancy and Its Risk Factors Among Pregnant Women in Tehran, Iran. Nursing and Midwifery Studies, 5(3). https://doi.org/10.17795/. nmsjournal29740

Nawati, N., \& Nurhayati, F. (2018). Dampak Kehamilan Tidak Diinginkan terhadap Perawatan Kehamilan dan Bayi (Studi Fenomenologi) di Kota Bogor. Jurnal Kesehatan, 9(1), 21-25.

Padila, N. (2012). Buku Ajar Keperawatan Medikal Bedah. Yogyakarta: Nuha Medika.

Pohan, N. H. (2017). Faktor yang berhubungan dengan pernikahan usia dini terhadap remaja putri. Labuhanbatu. Jurnal Endurance, 2(3); 424-435

Prawardani, S., Aryawati, W., \& Kurniasari, D. (2015). ANALISISFAKTORYANG BERHUBUNGAN DENGAN KEJADIAN KEHAMILAN PADA REMAJA DI WILAYAH KERJA PUSKESMAS SERUPA INDAH KECAMATAN PAKUAN RATU WAY KANAN TAHUN 2014. Holistik Jurnal Kesehatan, 9(1).

Presiden RI. (2019). Undang-Undang Republik Indonesia Nomor 16 Tahun 2019 tentang Perubahan atas Undang-Undang Nomor 1 Tahun 1974 tentang Perkawinan. 65-73. Jakarta.

Priyoto. (2014). Teori Sikap dan Perilaku dalam Kesehatan. Yogyakarta: Nuha Medika.

Ramadani, M. (2017). Dukungan keluarga sebagai faktor dominan keberhasilan menyusui eksklusif. Media Kesehatan Masyarakat Indonesia, 13(1), 34-41.

Realita, F., \& Meiranny, A. (2018). Peran Pendidikan Dan Pendapatan Terhadap Kehamilan Remaja. Jurnal SMART Kebidanan, $\quad 5(1), \quad 11$. https://doi.org/10.34310/sjkb.v5i1.147

Santrock, John W.(2009). Perkembangan Anak. Edisi 11. Jakarta. Erlangga

Sarwono, S. W. (2013). Psikologi Remaja. Jakarta: PT. Raja Grafindo Persada.

Singh, P. K., Rai, R. K., Alagarajan, M., \& Singh, L. (2012). Determinants of maternity care services utilization among married adolescents in rural India. PloS one, 7(2), e31666.

Suhardi. (2012). Pengembangan Sumber Belajar Biologi. Yogyakarta: Jurdik.

Sulistianingsih, A. (2010). Hubungan lingkungan pergaulan dan tingkat pengetahuan tentang kesehatan reproduksi dengan sikap seks bebas pada remaja. [Skripsi]. Surakarta: Fakultas Kedokteran, Universitas Sebelas Maret.

Syafangah, U. dan I. (2017). Hubungan Tingkat Pendidikan Dan pekerjaan Dengan Pernikahan Dini Pada remaja Putri Di Kecamatan Gamping Kabupaten Sleman 2016. Naskah Publikasi, 1-15. http://digilib.unisayogya.ac.id/2593/1/NAS KAH PUBLIKASI UMI SYAFANGAH $\% 281610104475 \% 29$.pdf

Widyoningsih. 2011. Pengalaman Keluarga Merawat Anak Remaja dengan Kehamilan Tidak Diinginkan (KTD) Di Kabupaten Cilacap Provinsi Jawa Tengah: Studi Fenomenologi. [Tesis]. Depok: Magister Keperawatan Fakultas Ilmu Keperawatan. Universitas Indonesia.

Yuniarti, S., Setiowati, T., \& Aisyah, S. (2011). Hubungan Pengetahuan Dengansikap Remaja Putri Tentang Kehamilan Usia Dini Di Desa Ciwareng Kecamatan Babakan Cikao Kabupaten Purwakarta Tahun 2011. [Naskah Publikasi]. Cimahi: STIKES Jenderal Achmad Yani Cimahi. 